\title{
ANALISIS KINERJA RANTAI PASOK AGROINDUSTRI KAKAO DI KABUPATEN LIMA PULUH KOTA, PROVINSI SUMATERA BARAT
}

\section{PERFORMANCE ANALYSIS OF KAKAO AGROINDUSTRY SUPPLY CHAIN IN LIMA PULUH KOTA REGENCY, WEST SUMATERA PROVINCE}

\author{
Peni Shoffiyati ${ }^{1 *}$, Melinda Noer ${ }^{2)}$, Rahmat Syahni ${ }^{2)}$, Asrinaldi ${ }^{3)}$ \\ ${ }^{1)}$ Program Studi Ilmu Pertanian, Pasca Sarjana, Universitas Andalas, \\ Limau Manis, Padang, 25136, Indonesia \\ Email: peni_rey@yahoo.com \\ ${ }^{2}$ Sosial Ekonomi Pertanian, Fakultas Pertanian, Universitas Andalas, Limau Manis, Padang, Indonesia \\ ${ }^{3)}$ Ilmu Sosial Politik, Fakultas ISIP, Universitas Andalas, Limau Manis, Padang, 25136, Indonesia \\ Makalah: Diterima 27 Agustus 2018; Diperbaiki 11 Desember 2018; Disetujui 10 Januari 2019
}

\begin{abstract}
Implementation of supply chain management concepts is needed to meet consumer demand for agricultural products which include overall management of production, distribution and marketing processes that can be measured through the measurement of supply chain performance. Supply chain performance is the integration of supply chain activities, to enhance relationships to gain competitive advantage. Cocoa commodity is one of the leading commodities in West Sumatera, and Kabupaten Lima Puluh Kota is one of the locus of cocoa agroindustry. This study aimed to determine the supply chain system of cocoa agroindustry in Kabupaten Lima Puluh Kota in terms of material, information and financial flow of each involved actors, and to measure how the performance of the cocoa agro-industry supply chain in Kabupaten Lima Puluh Kota. The study used a questionnaire through the SCOR (Supply Chain Operation Reference) method with reliability, responsiveness, agility, cost and asset management attributes. The result of the research showed that in cocoa agro-industry supply chain there was a material flow of cocoa from farmer to cocoa processing agroindustry "Chokato", then processed cocoa products were sold to consumers (end consumers or consumers of IKM processing cocoa products). The information flow among actors included the quantity and price of cocoa that can be supplied and the quantity and price of processed cocoa products produced by cocoa processing agroindustry. In the financial flow, the value of purchases and sales value of magnitude were in line with the amount of material flow that exists between the actors in the supply chain system of cocoa agro-industry. The result of supply chain performance measurement was obtained that the highest importance level was at cost attribute equal to 4,84 in 1-5 scale meaning that in the supply chain of cocoa agrondustry was very important to the ability of supply chain entity in fulfillment of cost related to supply chain process, which will determine efficiency in product supply.
\end{abstract}

Keywords: cocoa agroindustry, supply chain performance

\section{ABSTRAK}

Penerapan konsep manajemen rantai pasok diperlukan dalam memenuhi permintaan konsumen akan produk pertanian yang meliputi pengelolaan keseluruhan proses produksi, distribusi dan pemasaran yang diukur melalui pengukuran kinerja rantai pasok. Kinerja rantai pasok adalah integrasi aktifitas rantai pasokan, sampai meningkatkan hubungan untuk mendapatkan keunggulan bersaing. Komoditi kakao menjadi komoditi unggulan di Sumatera Barat, dan Kabupaten Lima Puluh Kota menjadi salah satu lokus dari agroindustri kakao. Penelitian bertujuan untuk mengetahui sistem rantai pasok agroindustri kakao Kabupaten Lima Puluh Kota ditinjau dari aliran material, informasi dan keuangan masing-masing pelaku yang terlibat, dan mengukur kinerja rantai pasok agroindustri kakao Kabupaten Lima Puluh Kota. Penelitian menggunakan kuisioner melalui metode SCOR (Supply Chain Operation Reference) dengan atribut reliability, responsiveness, agility, cost dan asset management. Hasil penelitian menunjukan pada sistem rantai pasok agroindustri kakao terdapat aliran material berupa kakao dari petani ke agroindustri pengolahan kakao "Chokato", kemudian produk olahan kakao yang dihasilkan dijual ke konsumen (konsumen akhir ataupun konsumen IKM pengolahan produk kakao). Aliran informasi antar pelaku meliputi jumlah dan harga kakao yang dapat dipasok dan jumlah dan harga produk olahan kakao yang diproduksi agroindustri pengolahan kakao. Aliran keuangan diindikasikan dengan nilai pembelian dan nilai penjualan yang besarnya seiring dengan jumlah aliran material antar pelaku pada sistem rantai pasok agroindustri kakao. Hasil pengukuran kinerja rantai pasok menunjukan tingkat kepentingan tertinggi pada atribut cost sebesar 4,84 dalam skala 1 sampai 5, artinya pada rantai pasok agrondustri kakao sangat dipentingkan kemampuan entitas rantai pasok dalam pemenuhan biaya yang terkait proses rantai pasok, yang menentukan efisiensi dalam penyediaan produk.

Kata kunci : agroindustri kakao, kinerja rantai pasok 


\section{PENDAHULUAN}

Penerapan konsep manajemen rantai pasok diperlukan dalam memenuhi permintaan konsumen atas produk pertanian, baik permintaan sebagai bahan baku untuk agroindustri maupun permintaan produk segar yang langsung dikonsumsi, sehingga para pelaku rantai pasok dapat memperoleh manfaat, mulai dari hulu (petani) sampai ke hilir (konsumen akhir). Rantai pasok diartikan sebagai urutan dari proses pengambilan keputusan mengenai aliran bahan, informasi dan uang yang dilakukan secara bersama untuk memenuhi suatu produk ke tangan konsumen akhir secara kontinu. Manajemen rantai pasok dipandang sebagai metode, alat, atau pendekatan pengelolaan, keterpaduan perencanaan, implementasi, koordinasi, dan pengendalian semua proses, dan kegiatan bisnis untuk memproduksi dan mengirimkan produk secara efisien untuk memenuhi kebutuhan pasar, dan mengintegrasikan secara efisien para pemasok, pabrikasi, pergudangan, dan penyimpanan, sehingga barang-barang diproduksi dan didistribusikan dengan jumlah yang benar, lokasi yang benar, dan saat yang tepat dalam rangka minimisasi biaya, sistem secara keseluruhan, sekaligus memenuhi seluruh kebutuhan disetiap tingkatan (Vorst et al, 2007; Pujawan, 2005; SimchiLevi et al., 2000). Pengelolaan manajemen rantai pasok merupakan pengelolaan keseluruhan proses produksi, distribusi dan pemasaran yang dapat diukur melalui pengukuran kinerja rantai pasok.

Kinerja rantai pasok diartikan sebagai integrasi dari seluruh aktifitas dalam rantai pasokan, sampai meningkatkan hubungan untuk mendapatkan keunggulan bersaing, dimana integrasi tersebut sistematik, koordinasi yang strategis dari fungsifungsi bisnis tradisional dan taktik-taktik melalui fungsi-fungsi bisnis tersebut dalam sebuah perusahaan dan melalui bisnis dalam rantai pasokan, dengan tujuan meningkatkan performa jangka panjang dari perusahaan individu dan rantai pasokan sebagai keseluruhan (Ballou, 2005). Pengukuran kinerja rantai pasok dapat menggunakan Supply Chain Operation References (SCOR) (Irfan, 2008; Wayyun, 2010; Jamehshooran, 2015). Penerapan model SCOR dapat mengidentifikasi indikator kinerja rantai pasok dengan menunjukan proses rantai pasok perusahaan, sehingga dapat dijadikan evaluasi dalam meningkatkan kinerja (Kurien, 2012; Ambe, 2014; Susanty, 2017).

Industri pengolahan kakao menjadi salah satu komoditi unggulan yang ada di Sumatera Barat. Kontribusi Sumatera Barat akan produksi kakao Indonesia mencapai $7,73 \%$, dan Kabupaten Lima Puluh Kota menjadi salah satu lokus dari agroindustri kakao Sumatera Barat (BPS, 2016; Dinas Tanaman Pangan, Hortikultura dan Perkebunan Provinsi Sumatera Barat, 2018). Permasalahan pada agroindustri kakao khususnya di Sumatera Barat seperti pada penelitian Hasan (2017) menunjukkan bahwa rendahnya adopsi teknologi petani kakao karena tingkat pendidikan dan pengalaman masih kurang. Inovasi teknologi budidaya dan mutu yang dibutuhkan oleh petani di kedua sentra produksi kakao di Sumatera Barat adalah pemangkasan, pemupukan, sambung samping, sanitasi kebun, pengendalian hama penyakit, fermentasi, dan pengeringan biji kakao. Rata-rata peningkatan adopsi inovasi teknologi setelah diseminasi di Kabupaten Padang Pariaman dan Pasaman, masing-masing sebesar $45,54 \%$ dan $53,31 \%$. Permasalahan lainnya menurut penelitian Danil (2014) meliputi kurang efisiennya pemasaran kakao dengan indikator besarnya margin pemasaran dan kecilnya bagian harga yang diterima petani. Pada hasil penelitiannya ditunjukkan dengan ada kegiatan pemasaran kakao di Kabupaten Padang Pariaman, margin terbesar diterima oleh pedagang nagari pada saluran pemasaran III (saluran pemasaran yang digunakan petani ke pedagang nagari dan kemudian langsung ke pedagang kabupaten). Bagian harga yang diterima petani dapat ditentukan dari margin pemasaran, yaitu semakin besar margin pemasaran maka bagian harga yang diterima petani akan semakin kecil.

Melihat permasalahan pada agroindustri kakao tersebut, maka penting dilakukan penelitian untuk melihat sistem rantai pasok agroindustri kakao saat ini yang ditinjau dari aliran material, aliran informasi dan aliran uang antar para pelaku rantai pasok, dan mengukur kinerja rantai pasok agroindustri kakao yang ada pada saat ini.

\section{METODE PENELITIAN}

Penelitian dilakukan di kabupaten Lima Puluh Kota pada bulan April 2018. Sebagai focal firm agroindustri kakao pada kabupaten tersebut adalah pengolahan kakao "Chokato". Penelitian ini dilakukan dengan menggunakan data primer dan sekunder. Data primer diperoleh melalui wawancara langsung kepada pelaku rantai pasok agroindutstri kakao yaitu 8 orang petani kakao, 2 pedagang pengumpul, pemilik pengolahan kakao "Chokato", IKM pengolahan coklat, dan konsumen secara purposive sampling. Data sekunder diperoleh melalui pihak dan instansi yang terkait yakni Dinas Perkebunan, Dinas ketahanan Pangan \& Hortikultura, Dinas Perindustrian Perdagangan dan Koperasi Provinsi Sumatera Barat, Badan Pusat Statistik dan juga melalui penelaahan pustaka. Tahapan penelitian dimulai dari identifikasi masalah, studi pustaka, menentukan sumber data, menyusun instrumen penelitian, pengumpulan data di lapangan, pengolahan data, analisis data dan menarik kesimpulan. Adapun Metode deskriptif digunakan untuk tujuan pertama yaitu menjelaskan sistem rantai pasok agroindustri kakao pada Kabupaten Lima Puluh Kota. Adapun untuk menjawab tujuan kedua yaitu menganalisis kinerja rantai pasok agroindustri kakao pada Kabupaten Lima Puluh 
Kota menggunakan kuisioner dengan metode SCOR dengan atribut reliability, responsiveness, agility, cost dan asset management (Supply Chain Council, 2009). Penilaian terhadap pentingnya indikator pada setiap atribut diberikan dalam skala likert 1 sampai 5 pada masing-masing pertanyaan di dalam perangkat kuisioner.

\section{HASIL DAN PEMBAHASAN}

Penelitian ini menggambarkan kondisi rantai pasok agroindustri kakao di Kabupaten Lima Puluh Kota khusuSnya pengolahan kakao "Chokato" sebagai focal firm. Berdasarkan gambaran yang diperoleh dilakukan penilaian terhadap kinerja rantai pasok tersebut.

\section{Sistem Rantai Pasok Agroindustri Kakao di Kabupaten Lima Puluh Kota}

Pada rantai pasok ada tiga macam aliran yang harus dikelola yaitu aliran barang, aliran informasi dan aliran uang. Aliran barang yang mengalir dari hulu ke hilir adalah berupa aliran bahan baku yang dikirim dari pemasok. Aliran informasi yang terjadi bisa dari hulu ke hilir ataupun sebaliknya berupa informasi harga beli maupun harga jual, informasi jumlah bahan baku yang dipasok maupun jumlah produk yang dijual. Aliran uang yang mengalir dari hilir ke hulu adalah berupa nilai jual dari bahan baku yang dijual ataupun produk yang dibeli (Pujawan, 2005). Sistem rantai pasok pada agroindustri kakao di Kabupaten Lima Puluh Kota dapat ditinjau dari aliran barang, aliran informasi dan aliran uang pada Gambar 1 .

\section{Aliran Barang \\ Petani}

Petani kakao pada Kabupaten Lima Puluh Kota khususnya terbagi menjadi kelompok tani dan petani mandiri yang tidak berkelompok. Petani yang memasok kebutuhan biji kakao pada pengolahan kakao "Chokato" merupakan kelompok tani mitra dan juga ada petani mandiri sekitar. Sedangkan pengolahan kakao "Chokato sendiri dikelola oleh kelompok tani Tanjung Subur. Bahan baku yang dipasok dari kelompok tani merupakan biji kakao mentah dan ada juga yang biji kakao terfermentasi.

Biji kakao yang mentah akan difermentasi oleh anggota kelompok tani yang mengelola pengolahan kakao "Chokato, khususnya dibagian fermentasi. Proses fermentasi dilakukan dalam kotak khusus yang berukuran $\pm 40 \mathrm{~kg}$ biji kakao selama 4 5 hari yang akan menghasilkan biji kakao $\pm 13 \mathrm{Kg}$ dan pada akhir proses fermentasi, dengan kadar air mencapai 7-8 \%. Harga biji kakao mentah tidak terfermentasi dihargai sekitar Rp 30.000 per kg, adapun biji kakao yang telah fermentasi dihargai sekitar Rp 35.000 per kg. Perbedaan kakao yang dijual oleh petani mandiri dan kelompok tani lebih kepada keseragaman kualitas biji yang dijual.

\section{Pedagang Pengumpul}

Pedagang pengumpul membeli kakao dari yang dihasilkan dari petani mandiri yang tidak bermitra dengan pengolahan kakao "Chokato". Para pedagang pengumpul kakao biasanya menerima kakao dalam keadaan biji kakao mentah yang belum terfermentasi.

\section{Pengolahan Kakao "Chokato”}

Pengolahan kakao "Chokato" merupakan pabrik pengolahan kakao yang dikelola oleh kelompok tani Tanjung Subur. Pengolahan kakao "Chokato" berdiri pada akhir tahun 2011 dan mulai berproduksi pada Februari 2012. Kelompok tani beranggotakan 21 orang, tetapi hanya 8 orang anggota kelompok tani yang ikut mengelola pabrik dan 8 orang tersebut juga memiliki lahan kakao. Pengolahan kakao "Chokato" mendapatkan bahan baku dari hasil usahatani kelompok tani Tanjung Subur, kelompok tani lainnya serta dari masyarakat sekitar.

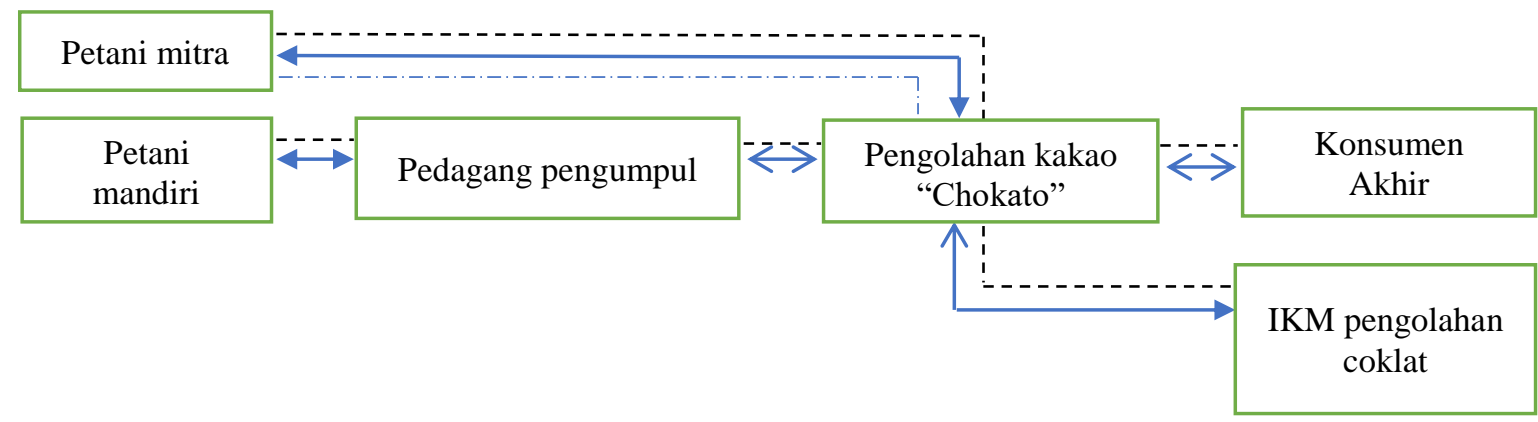

Gambar 1. Aliran barang, aliran informasi dan aliran uang pada rantai pasok kakao Kabupaten Lima Puluh Kota

Keterangan :

$\longleftrightarrow$ : aliran barang dan aliran uang

- - - : : aliran informasi harga

: aliran informasi jumlah bahan baku 
Pengolahan kakao "Chokato" menerima biji kakao fermentasi dan biji kakao yang mentah dan belum difermentasi. Biji kakao yang mentah dan belum difermentasi akan difermentasi oleh anggota kelompok tani yang mengelola pabrik, khususnya dibagian fermentasi. Produk yang dihasilkan pengolahan kakao "Chokato" meliputi bubuk coklat murni, bubuk coklat $3 \mathrm{n} 1$, lemak coklat dan berbagai kemasan permen coklat.

\section{Konsumen}

Setelah kakao yang diproses menjadi produk olahan kakao di pengolahan kakao "Chokato" maka siap dikonsumsi oleh konsumen. Konsumen produk olahan kakao tersebut meliputi IKM pengolahan produk coklat (dari Sijunjung, Yogyakarta, Bandung) yang membeli lemak coklat dari pengolahan kakao "Chokato". Konsumen lainnya adalah konsumen akhir yang membeli produk Chokato untuk dikonsumsi sendiri.

Adapun aliran barang yang terjadi pada rantai pasok kakao pada Kabupaten Lima Puluh Kota dapat dijelaskan pada Tabel 1.

\section{Aliran Informasi}

Faktor kunci untuk mengoptimalkan rantai pasok adalah dengan menciptakan aliran informasi yang bergerak secara mudah dan akurat diantara pelaku rantai pasok tersebut. Informasi tersebut misalnya mengenai informasi ketersediaan dan harga produk, informasi ketersediaan kapasitas produksi, dan informasi status pengiriman bahan baku. Dengan tercapainya koordinasi dari rantai pasok antar pelaku, maka tiap pelaku rantai pasok tidak akan mengalami kekurangan barang dan juga tidak akan kelebihan barang terlalu banyak (Pujawan, 2005). Adapun aliran informasi yang terjadi pada rantai pasok kakao pada Kabupaten Lima Puluh Kota dijelaskan pada Tabel 2.

\section{Aliran Uang}

Selain aliran material dan aliran informasi, aliran yang terjadi pada sistem rantai pasok adalah aliran uang. Pada Tabel 3 menjelaskan aliran uang yang terjadi pada sistem rantai pasok kakao pada Kabupaten Lima Puluh Kota.

Tabel 1.Aliran barang yang ada pada rantai pasok kakao pada Kabupaten Lima Puluh Kota

\begin{tabular}{|c|c|c|}
\hline No & Pelaku & Aliran uang \\
\hline 1 & Petani & $\begin{array}{l}\text { - Petani mitra menjual kakao ke Pengolahan kakao "Chokato" } \\
\text { - Petani mandiri menjual kakao ke pedagang pengumpul dan ada juga yang } \\
\text { dijual ke Pengolahan kakao "Chokato" }\end{array}$ \\
\hline 2 & Pedagang pengumpul & $\begin{array}{l}\text { Membeli kakao dari petani yang tidak bermitra dengan Pengolahan kakao } \\
\text { "Chokato" }\end{array}$ \\
\hline 3 & $\begin{array}{l}\text { Pengolahan kakao } \\
\text { "Chokato" }\end{array}$ & $\begin{array}{l}\text { - Membeli kakao dari petani mitra nya dan ada juga yang membeli kakao } \\
\text { dari masyarakat sekitar } \\
\text { - Produk oalahan hasil kakao dijual ke konsumen akhir ataupun ke IKM } \\
\text { pengolahan produk kakao }\end{array}$ \\
\hline 4 & Konsumen & $\begin{array}{l}\text { - Konsumen membeli produk olahan kakao dari Pengolahan kakao } \\
\text { "Chokato" yang terdiri dari konsumen akhir ataupun konsumen IKM } \\
\text { pengolahan produk kakao }\end{array}$ \\
\hline
\end{tabular}

Tabel 2. Aliran informasi yang ada pada rantai pasok kakao pada Kabupaten Lima Puluh Kota

\begin{tabular}{|c|c|c|}
\hline No & Pelaku Rantai Pasok & Aliran Informasi \\
\hline 1 & Petani & $\begin{array}{l}\text { - Memerlukan informasi harga kakao dari pedagang pengumpul } \\
\text { dan pengolahan kakao "Chokato" } \\
\text { - Memberikan informasi jumlah pasokan kakao kepada } \\
\text { pengolahan kakao "Chokato" sebagai mitranya }\end{array}$ \\
\hline 2 & Pedagang pengumpul & - Memerlukan info harga kakao dari eksportir \\
\hline 3 & Pengolahan kakao "Chokato" & $\begin{array}{l}\text { - Memberikan informasi harga kakao kepada para petani mitra } \\
\text { dan petani mandiri } \\
\text { - Memerlukan informasi jumlah kakao yang bisa dipasok dari } \\
\text { para petani mitra yang merupakan kelompok tani mitra } \\
\text { pengolahan kakao "Chokato" } \\
\text { Memberikan informasi harga produk olahan kakao kepada } \\
\text { para konsumen langsung maupun pada IKM pengolahan } \\
\text { produk kakao }\end{array}$ \\
\hline 4 & Konsumen & - Memerlukan informasi harga produk hasil olahan kakao \\
\hline
\end{tabular}


Tabel 3.Aliran keuangan yang ada pada rantai pasok kakao pada Kabupaten Lima Puluh Kota

\begin{tabular}{cll}
\hline No & \multicolumn{1}{c}{ Pelaku } & \multicolumn{1}{c}{ Aliran uang } \\
\hline 1 & Petani & Hasil penjualan berdasarkan harga realisasi jual kakao \\
2 & Pedagang pengumpul & - Biaya pembelian berdasarkan harga realisasi beli kakao dari petani \\
& & - Hasil penjualan berdasarkan harga realisasi jual kakao \\
3 & $\begin{array}{l}\text { Pengolahan kakao } \\
\text { "Chokato" }\end{array}$ & - Biaya pembelian berdasarkan harga realisasi beli kakao dari petani \\
& - Hasil penjualan berdasarkan harga realisasi jual produk olahan kakao \\
& Konsumen & - Biaya pembelian berdasarkan harga realisasi beli produk olahan kakao \\
& & - Khusus konsumen IKM pengolahan produk kakao adalah berupa hasil \\
& & penjualan berdasarkan harga realisasi jual produk olahan coklat \\
& &
\end{tabular}

\section{Analisa Kinerja Rantai Pasok Agroindustri Kakao Pada Kabupaten Lima Puluh Kota}

Berdasarkan sistem rantai pasok yang telah dijabarkan, akan dianalisis kinerja rantai pasok dengan menggunakan kuisioner meliputi 5 (lima) atribut kinerja yaitu supply chain reliability, supply chain responsiveness, supply chain agility, supply chain cost dan supply chain asset management. Dimana batasan pada penelitian ini seperti yang telah dikemukakan pada bagian metodologi bahwa pengukuran kinerja rantai pasok agroindustri kakao yang dimaksud menggunakan pengolahan kakao "Chokato" sebagai focal firm nya.

\section{Supply Chain Reliability}

Reliability (kehandalan) menggambarkan kemampuan dalam melaksanakan pekerjaan sesuai dengan yang diharapkan. Reliability berfokus pada proses yang hasilnya dapat diramalkan. Reliability juga berkaitan dengan kemampuan melaksanakan setiap pekerjaan sesuai dengan yang direncanakan. Fokus dari reliability adalah ketepatan waktu, ketepatan kuantitas dan ketepatan kualitas (Paul, 2014). Pengolahan kakao "Chokato" dianggap cukup baik dalam memasarkan produknya. Perihal pengiriman produk dengan kualitas yang baik kepada konsumen, pengiriman jumlah produk yang tepat sesuai permintaan konsumen, pengiriman jenis produk yang tepat kepada konsumen, dan penerimaan barang return dari konsumen jika terjadi kerusakan pada produk ataupun permasalahan lainnya sesuai waktu garansi, sangat menjadi faktor penting pada pengolahan kakao "Chokato". Lamanya proses return produk pada pengolahan kakao "Chokato" berkisar 7 hari.

Pada perihal pendokumentasian segala kegiatan pengiriman dan jual beli ataupun berkaitan dengan inventory pada pengolahan kakao "Chokato" belum sepenuhnya dilaksanakan. Hal tersebut dikarenakan adanya keterbatasan sumberdaya manusia yang khusus dalam pengelolaan administrasi hal tersebut.

\section{Supply Chain Responsiveness}

Responsiveness menggambarkan kecepatan berulang pada setiap pekerjaan yang dilakukan pada proses rantai pasok dalam menyediakan produk untuk konsumen. Responsiveness juga berkaitan dengan kecepatan waktu respon setiap pelaksanaan fungsi-fungsi yang berada di setiap mata rantai (Paul, 2014). Jangka waktu pengiriman produk pengolahan kakao "Chokato" ke konsumen biasanya tegantung jarak kota pemesan. Perihal pengadaan bahan baku dari petani sebagai pemasok kakao, pengolahan kakao "Chokato" mendapat kepastian pasokan yang terjamin dikarenakan pengolahan kakao "Chokato" mempunyai kelompok tani yang menjadi mitranya. Produk olahan kakao yang dijual oleh pengolahan kakao "Chokato" sendiri sebenarnya cukup mudah didapatkan oleh konsumen.

\section{Supply Chain Agility \\ Agility merupakan atribut yang menggambarkan kemampuan untuk merespon} pengaruh eksternal, dan kemampuan untuk berubah atas pengaruh tersebut. Pengaruh eksternal termasuk peningkatan atau penurunan permintaan yang tidak terduga, bencana alam, terorisme, kondisi keuangan, masalah pekerja dan sebagainya. Inti dari agility yaitu fleksibilitas dan kemampuan beradaptasi. Artinya agility juga berkaitan dengan kemampuan untuk fleksibel dan beradaptasi dalam menghadapi setiap perubahan yang disebabkan oleh faktor eksternal (Paul, 2014).

Dalam menjalankan proses bisnisnya pengolahan kakao "Chokato" dianggap cukup bisa menyelesaikan permasalahan produksi seperti terlaksananya proses produksi sesuai jadwal, pengelolaan persedian, hingga permasalahan dengan pihak lain yang terlibat. Sebagai contoh, pengolahan kakao "Chokato" selalu mengadakan persediaan produk sebagai langkah antisipasi jika ada produk yang dikembalikan oleh konsumen karena kondisi tertentu. Jadwal produksi pengolahan kakao "Chokato" setiap minggunya adalah enam hari kerja dari hari Senin sampai dengan hari Sabtu.

\section{Supply Chain Cost}

Atribut cost menggambarkan kemampuan untuk pemenuhan biaya biaya terkait dengan proses rantai pasok. Cost juga berkaitan dengan biaya-biaya di dalam rantai pasok. Termasuk di dalamnya terdapat labor costs, material costs, management 
and transportation costs (Paul, 2014). Biaya utama yang muncul antara petani, pengolahan kakao "Chokato" dan konsumen adalah biaya pembelian. Pengolahan kakao "Chokato" mengeluarkan biaya pembelian bahan baku kakao ke petani.

Pengolahan kakao "Chokato" merupakan agroindustri pengolahan kakao yang beranggotakan kelompok tani Tanjung Subur. Kelompok tani beranggotakan 21 orang, tetapi hanya 8 orang anggota kelompok tani yang ikut mengelola dan 8 orang tersebut juga memiliki lahan kakao. Sistem upah atau gaji dari tenaga kerja di pengolahan kakao "Chokato" disebut dengan insentif yang diterima sebulan sekali. Adapun insentif yang diberikan kepada anggota kelompok tani yang mengelola pengolahan kakao "Chokato", yaitu Rp 1.500.000 per bulan.

\section{Supply Chain Asset Management}

Atribut asset management menggambarkan kemampuan efektifitas organisasi dalam manajemen aset untuk mendukung pemenuhan permintaan. Asset management efficiency atau efisiensi dalam pengelolaan asset berkaitan dengan utilitas nilai suatu barang, penyusutan inventory, insourcing ataupun outsourcing (Paul, 2014). Pengolahan kakao "Chokato" selama ini dapat dikatakan cukup mampu untuk mencapai target penjualan yang ditentukan dengan target produksi $100-120 \mathrm{~kg}$ biji kering kakao per minggu. Hal tersebut mengharuskan pengolahan kakao "Chokato" mampu untuk mengelola inventory, dan dapat beroperasi dengan inventory produk yang ada. Kemampuan kecepatan dalam mengubah asset menjadi uang ditunjukkan dengan tidak adanya sistem bon pada penjualan produk pengolahan kakao "Chokato".

Berdasarkan analisis kinerja rantai pasok dengan menggunakan atribut SCOR di atas, penelitian ini menghasilkan bahwa ternyata atribut cost pada pengolahan kakao "Chokato" merupakan atribut yang mempunyai tingkatan lebih penting dibandingkan dengan empat atribut lainnya. Hal ini ditunjukan pada Tabel 4.

Pada Tabel 4 atribut reliability menunjukkan kemampuan rantai pasok dalam melaksanakan pekerjaan sesuai dengan yang diharapkan. Atribut responsiveness artinya kecepatan berulang pada setiap pekerjaan yang dilakukan pada proses rantai pasok dalam menyediakan produk untuk konsumen serta kecepatan waktu respon dalam setiap perubahan yang ada. Atribut agility menunjukkan kemampuan rantai pasok untuk merespon pengaruh eksternal, dan kemampuan untuk berubah atas pengaruh tersebut. Atribut cost artinya pemenuhan biaya biaya terkait dengan proses rantai pasok. Atribut asset management menunjukkan kemampuan efektifitas organisasi dalam manajemen aset untuk mendukung pemenuhan permintaan

Hasil perhitungan ditinjau dari tingkat kepentingan menunjukkan atribut cost mempunyai kepentingan terbesar yaitu 4,84, menyusul kemudian atribut agility, asset management, reliability, dan responsiveness. Artinya pada rantai pasok agrondustri kakao sangat dipentingkan kemampuan entitas rantai pasok dalam pemenuhan biaya yang terkait proses rantai pasok, yang nantinya akan menentukan efisiensi dalam penyediaan produk pertanian tersebut dan akhirnya tujuan dari pembangunan pertanian akan tercapai yaitu memberikan manfaat terhadap para pelaku yang terlibat pada rantai pasok suatu komoditi pertanian.

\section{KESIMPULAN DAN SARAN}

\section{Kesimpulan}

Hasil penelitian menunjukkan pada sistem rantai pasok agroindustri kakao terdapat adanya aliran material berupa kakao dari petani ke agroindustri pengolahan kakao "Chokato" ataupun ke pedagang pengumpul, kemudian produk olahan kakao yang dihasilkan dijual ke konsumen (konsumen akhir ataupun konsumen IKM pengolahan produk kakao). Aliran informasi antar pelaku meliputi jumlah dan harga kakao yang dapat dipasok dan jumlah dan harga produk olahan kakao yang diproduksi agroindustri pengolahan kakao. Pada aliran keuangan, terdapat nilai pembelian dan nilai penjualan yang besarnya seiring dengan jumlah aliran material yang ada antar para pelaku pada sistem rantai pasok agroindustri kakao. Hasil pengukuran kinerja rantai pasok didapatkan hasil bahwa tingkat kepentingan tertinggi ada pada atribut cost yaitu sebesar 4,84 artinya pada rantai pasok agrondustri kakao sangat dipentingkan kemampuan entitas rantai pasok (petani, pedagang pengumpul, pengolahan kakao, dan konsumen) dalam pemenuhan biaya yang terkait proses rantai pasok, yang nantinya akan menentukan efisiensi dalam penyediaan produk pertanian tersebut dan akhirnya tujuan dari pembangunan pertanian akan tercapai yaitu memberikan manfaat terhadap para pelaku yang terlibat pada rantai pasok suatu komoditi pertanian.

Tabel 4. Perhitungan atribut SCOR dalam pengukuran kinerja rantai pasok agroindustri kakao pada Kabupaten Lima Puluh Kota

\begin{tabular}{cccccc}
\hline & & Atribut & & Total SCOR \\
\hline Reliability & Responsiveness & Agility & Cost & $\begin{array}{c}\text { Asset } \\
\text { Management }\end{array}$ & \\
\hline 4,50 & 4,40 & 4,80 & 4,84 & 4,60 & 4,63 \\
\hline
\end{tabular}




\section{Saran}

Perihal yang terkait dari hasil penelitian ini yang dapat menjadikan saran untuk penelitian selanjutnya adalah pengukuran efisiensi harga yang dapat dilihat dari segi margin pemasaran, margin keuntungan, bagian petani dan efisiensi pemasaran.

\section{UCAPAN TERIMA KASIH}

Dalam kesempatan ini penulis menyampaikan ucapan banyak terima kasih kepada para komisi pembimbing, pimpinan dan segenap karyawan pada agroindustri pengolahan kakao "Chokato", pihak Dinas Perkebunan, pihak Dinas ketahanan Pangan \& Hortikultura, Dinas Perindustrian Perdagangan dan Koperasi Provinsi Sumatera Barat, dan segala pihak yang telah membantu dalam penulisan hasil penelitian ini.

\section{DAFTAR PUSTAKA}

Ambe IM. 2014. Key indicators for optimising SC performance: The case of light vehicle manufacturers in South Africa. The Journal Applied Business Research. 30 (1): 277-290.

Badan Pusat Statistik Provinsi Sumatera Barat. 2016. Provinsi Sumatera Barat Dalam Angka 2016. Badan Pusat Statistik Provinsi Sumatera Barat.

Ballou RH. 2005. Business Logistic Management. Fifth Edition, New Jersey: Prectice Hall, Upper Saddle River.

Danil MF dan Hartoyo S. 2014. Produksi dan pemasaran kakao di kabupaten padang pariaman, Provinsi Sumatera Barat. Jurnal Manajemen \& Agribisnis. 11 (1) : 41-51

Hasan N dan Roswita R. 2017. Peningkatan adopsi teknologi dan mutu kakao di Provinsi Sumatera Barat. Jurnal Tanaman Industri dan Penyegar. 4 (1): 23-30.

Irfan D, Xiaofei X, dan Chun DS. 2008. A SCOR reference model of the SC: Management system in a enterprise. International Arab Journal Information Technology. 5 (3): 288-295.
Jamehshooran BG, Awaluddin MS, dan Habibah NH. 2015, Assessing SC performance through applying the SCOR Model. Int. Journal Supply Chain Management. 4 (1): 1-11.

Kurien GP dan Qureshi MN. 2012. Performance measurement systems for green SCs using modified balanced score card and analytical hierarchical process. Scientific Research and Essays. 7 (36) : 3149 3161.

Paul J. 2014. Transformasi Rantai Suplai Dengan Model SCOR. Jakarta: PPM Manajemen.

Pujawan IN. 2005. Supply Chain Manajemen. Surabaya: Guna Widya Publisher.

Simchi-Levi D, Kaminsky P, dan Simchi-Levi E. 2000. Designing and Managing the Supply Chain : Concept, Strategies And Case Studies. Singapore: The MSGrawHill Company, Inc.

Susanty A, Santosa H, dan Tania F. 2017. Penilaian implementasi Green Supply Chain Management di UKM Batik Pekalongan dengan Pendekatan GreenSCOR. Jurnal Ilmiah Teknik Industri.16 (1): 55 - 63.

Supply Chain Council. 2008. Supply Chain Operations Reference Model SCOR version 9.0 Metric, Washington DC. http://id.scribd. com/doc/4780677/Supply-Chain-Op erationSCOR-9\#scribd. [3 Desember 2014].

Vorst JG, Van der AJ, Silva CAD, Trienekens JH. 2007. Agroindustrial Supply Chain Managemen : Concepts and Applications Agricultural Management, Marketing and Finance Occasional Paper. Roma: Food and Agriculture Organization of The United Nations.

Wayyum R, Ahmad S, dan Usman M. 2010. Effects of SCOR on management of SC. International Journal Management \& Organizational Studies. 2 (1): 85 - 91. 